УДК 339.172 DOI: https://doi.org/10.30977/PРВ.2226-8820.2021.27.136

JEL Classification: Q 02

\title{
НАПРЯМИ АНАЛІЗУ БІРЖОВОЇ ДІЯЛЬНОСТІ В УКРАЇНІ
}

Нестеренко В.Ю., канд. екон. наук, доцент

Харківський національний автомобільно-дорожній університет

Сідельнікова В.К., канд. пед. наук, доцент

Харківський національний педагогічний університет імені

\section{Г.С. Сковороди}

Постановка проблеми. Біржова діяльність $є$ важливою ринковою умовою розвитку економіки будь-якої держави. Саме цей вид економічних відносин створює умови для поширення свободи конкуренції та забезпечує прозорість механізмів ціноутворення на головні сировинні, товарні, фінансові ресурси. Отже, забезпечення умов для розвитку біржової діяльності має бути однією з головних задач державного регулювання внутрішньої та зовнішньої торгівлі.

Аналіз останніх досліджень та публікацій. Проблемам дослідження біржового ринку в світі та в України присвятила увагу в своїх дослідженнях досить значна кількість науковців, таких як Бритвєнко А. С., Горяча О. Л., Войний I. І., Вавдійчук I.М., Дяченко Ю. А., Ковальчук С. В., Дражниця С. А., Карпенко В. Л., Резнік Н. П., Солодкий М. О. [1-6]. Однак головним чином, дослідження зосереджені на вивченні правових аспектів регулювання біржової діяльності, а також дослідженні статистики діяльності світових бірж.

Невирімені складові загальної проблеми. Не зважаючи на значну кількість досліджень, вимагає подальшого розгляду проблема формування системи напрямків аналізу біржової діяльності в Україні, з метою забезпечення дієвої та об'єктивної оцінки їх ефективності та реальної чисельності на ринку, а також якісного відображення в державній статистиці вартості угод, що укладаються.

Формулювання цілей статmі. Метою статті є формування переліку напрямів аналізу біржової діяльності в Україні та дослідження статистичних показників.

Виклад основного матеріалу дослідження. В сучасних ринкових умовах розвитку України органи ii державного управління повинні забезпечувати умови для розвитку вільних ринкових економічних відносин. Саме біржі $\epsilon$ уособленням вільної та прозорої торгівлі в ринкових умовах, бо саме завдяки їх діяльності:

- забезпечуються найвигідніші умови для всіх учасників торгів при укладанні угод;

- $\quad$ формуються прозорі ринкові ціни, які є результатом прямої взаємодії попиту та пропозиції на концентрованому ринку товару; 
- за рахунок концентрації покупців та постачальників відбувається перешкоджанням проявам монополізації ринків; торгівлі;

регулюється оптовий товарообіг в національній та міжнародній формується ефективна система інформаційного забезпечення всіх учасників торгів;

- формуються стандарти на біржові товари;

- стандартизуються умови торгівлі, постачання, форми розрахунків, тощо.

Однак в сучасних умовах України склалася ситуація, коли біржовий ринок виконує свої функції на дуже незадовільному рівні й не забезпечує реалізації вище названих аспектів біржової діяльності в ринкових умовах господарювання. Такі висновки можна зробити на основі наступних фактів:

за своєю економічною сутністю, біржа є постійно діючим оптовим ринком, однак, не зважаючи на вражаючу чисельність бірж в Україні, в порівнянні з більшістю інших країн світу, систематично діють серед них не більше $30 \%$ [7, 8];

- періодичні стрімкі зростання кількості бірж в Україні є результатом не підвищеного попиту на їх послуги з боку учасників торгів та результатом дії ринкових механізмів господарювання, а є відображенням впливу введення в дію законодавчих актів та обмежень у зовнішній торгівлі окремими групами товарів, таких як обов'язкова біржова реєстрація експортних контрактів, тощо.

- не зважаючи на велику кількість товарних бірж, які спеціалізуються на торгівлі агропромисловими товарами, в Україні все ще відсутній постійно діючий ефективний біржовий аграрний ринок.

Отже, кількісні статистичні показники, які характеризують діяльність бірж в Україні реально не відображають ситуацію на національному біржовому ринку. При цьому діяльності біржового ринку в сучасних умовах з боку державних органів приділяється настільки мало уваги, що з 2016 року навіть не ведеться офіційний статистичний аналіз та повністю відсутня офіційна статистика стосовно обсягів торгів в розрізі біржових угод - ведеться загальна статистика обсягів оптової торгівлі без індивідуалізації статистичних показників в розрізі товарних бірж.

Фактично єдиний статистичний аналіз, який стосується діяльності бірж в Україні ведеться лише по фондовим біржам Національною комісією з цінних паперів та фондового ринку [9].

Стосовно діяльності фондових бірж в Україні статистичний аналіз обсягів їх діяльності ведеться за наступними напрямками:

1) реєстрація випуску цінних паперів, а саме досліджується:

- обсяг та кількість випусків акцій, зареєстрованих Комісією;

- обсяг та кількість випусків облігацій підприємств, зареєстрованих Комісією;

2) реєстрація випусків цінних паперів інститутів спільного інвестування; 
3) аналіз діяльність операторів організованих ринків капіталу:

- обсяг торгів фінансовими інструментами на операторах організованих ринків капіталу;

- обсяг торгів фінансовими інструментами на операторах організованих ринків капіталу з розподілом за видом фінансового інструменту; - обсяг торгів фінансовими інструментами на операторах організованих ринків капіталу з розподілом за видом фінансового інструменту (у розрізі операторів організованих ринків капіталу);

- обсяг торгів фінансовими інструментами на операторах організованих ринків капіталу за видами ринку.

Отже, стосовно діяльності фондових бірж, можна зробити висновок про достатню увагу з боку державних керуючих органів до їх діяльності. Результати звітів Національної комісії з цінних паперів та фондового ринку за наведеними напрямками публікуються щоквартально та їх можна побачити у відкритому доступі. Також в Україні існує система публічного розкриття інформації про діяльність емітентів [10].

Стосовно ж діяльності товарних бірж в Україні ситуація виглядає принципово по іншому. Отже, необхідним $\epsilon$ створення механізмів, які б забезпечили об'єктивну оцінку їх діяльності з метою впровадження керуючих дій в напрямку їх розвитку в Україні.

Першочерговим $\epsilon$ створення прозорої системи формування статистичних даних про діяльність товарних бірж в Україні, які реально зможуть відобразити тенденції розвитку цього ринку. Для відповідного статистичного дослідження необхідне розкриття наступних груп інформації та розрахунок показників: дослідження кількості, структури, розмірів бірж, аналіз темпів зростання кількості у прямому зв'язку з обсягами укладених угод; аналіз обсягів попиту та пропозиції на біржах з метою виявлення формально діючих бірж; аналіз біржового обороту; аналіз показників ділової активності на біржовому ринку; аналіз біржових цін; аналіз обсягів строкових контрактів та похідних фінансових інструментів, як механізмів реалізації процедури хеджування; аналіз показників ефективності діяльності біржових установ та загальних показників галузі; аналіз показників розвитку біржової інфраструктури.

На сьогодні ж навіть статистичну інформацію стосовно кількості та структури бірж можна отримати за даними Державної служби статистики України [7] лише станом на 2015 рік. Показники за більш пізні терміни можна отримати лише на основі експертної думки дослідників [8].

Статистичні показники діяльності бірж в Україні станом на 2015 рік, без урахування показників тимчасово окупованих територій та території проведення ООС, наведені в табл. 1. 
Статистичні показники обсягів біржової діяльності в Україні

\begin{tabular}{|c|c|c|}
\hline \multirow{2}{*}{ Кількість зареєстрованих бірж } & \multicolumn{2}{|c|}{ Значення показника } \\
\cline { 2 - 3 } & Кількість, од. & $\begin{array}{c}\text { Питома вага у загальній } \\
\text { кількості, \% }\end{array}$ \\
\hline Кількість зареєстрованих бірж & 555 & 100 \\
\hline В тому числі: & 104 & 18,74 \\
\hline універсальні & 391 & 70,45 \\
\hline товарні та товарно-сировинні & 24 & 4,32 \\
\hline агропромислові & 36 & 6,49 \\
\hline інші & & \\
\hline
\end{tabular}

Складено авторами на основі [7]

Отже, як бачимо, переважна частина зареєстрованих бірж в Україні станом на 2015 рік - це товарні та товарно-сировинні біржі. Слід також, відмітити ще одну особливість ведення статистики кількості бірж в Україні загальна кількість визначається без урахування фондових бірж, статистичний аналіз яких фактично покладений на Національну комісію з цінних паперів та фондового ринку.

Стосовно показників кількості бірж у період після 2015 року, за думкою фахівців [8], їх прогнозна чисельність станом на 2020 рік є більшою за 600. Стосовно структури бірж, то загальна світова тенденція полягає у збільшенні частки товарних бірж, що пов'язане з загальною кризовою ситуацією в світі і поверненням уваги учасників біржових торгів саме до товарних контрактів.

Висновки з проведеного дослідження. Отже, сучасний стан аналізу показників діяльності біржової галузі в Україні знаходиться у незадовільному стані і вимагає негайного перегляду та суттєвого збільшення уваги через важливість біржової інфраструктури для системи реалізації ринкових механізмів в економіці.

\section{Перелік посилань}

1. Бритвєнко А. С., Горяча О. Л., Войний I. I. Організаційноекономічний механізм функціонування міжнародної електронної біржової торгівлі. Вісник Бердянського університету менеджменту $і$ бізнесу. 2020. № 1 (47). C. 9-14.

2. Вавдійчук I. М. Сучасний стан та тенденції розвитку біржової торгівлі в Україні. Глобальні та начіональні проблеми економіки. 2017. № 15. URL: http://global-national.in.ua/archive/15-2017/36.pdf (дата звернення: 15.09.2021).

3. Дяченко Ю. А. Сучасний стан та особливості фун кціонування світового біржового ринку. Науковий вісник Міжнародного гуманітарного університету. 2017. № 23. С. 51-54.

4. Ковальчук С. В., Дражниця С. А., Карпенко В. Л. Світові тренди та тенденції розвитку біржової торгівлі на сучасному етапі. Підприємництво $i$ торгівля. 2018. № 23. С. 10-14. 
5. Резнік Н. П. Особливості функціонування вітчизняного біржового товарного ринку у сучасних умовах. Збірник наукових праць Міжрегіональної Академії Управління персоналом. 2016. №. 50. С. 115-118.

6. Солодкий М. О. Проблеми та напрями розвитку біржового товарного ринку в Україні. Електронне наукове фахове видання "Ефективна економіка". 2017. № 10. URL: http://www.economy.nayka.com.ua/?op=1\&z=5814 (дата звернення: 05.09.2021).

7. Державна служба статистики України. Статистична інформачія. Внутрішня торгівля. Кількість бірж. URL: http://www.ukrstat.gov.ua/ (дата звернення: 10.09.2021).

8. Кухарець В. В., Булуй О. Г., Левківська Л. М. Тенденції розвитку біржового ринку в умовах глобалізації світової економіки. Електронне наукове фахове видання "Ефеективна економіка". 2021. № 4. URL: http://www.economy.nayka.com.ua/pdf/4_2021/92.pdf (дата звернення: 25.09.2021).

9. Національна комісія з цінних паперів та фондового ринку. Аналіз ринку. URL: https://www.nssmc.gov.ua/news/insights/ (дата звернення: 10.09.2021).

10. SMIDA. Емітенти. URL: https://smida.gov.ua/db/ (дата звернення: 12.09.2021).

\section{References}

1. Britvenko, A. S., Goryacha. O. 1., Vojniy, I. I. (2020). The organizational and economic mechanism of the functioning of the international electronic exchange trade [Orhanizatsiino-ekonomichnyi mekhanizm funktsionuvannia mizhnarodnoi elektronnoi birzhovoi torhivli], Bulletin of Berdyansk University of Management and Business, No. 1 (47), P. 9-14.

2. Vavdiichuk, I. M. (2017). Current state and trends of exchange trade development in Ukraine [Suchasnyi stan ta tendentsii rozvytku birzhovoi torhivli $\mathrm{v}$ Ukraini], Global and national economic problems., No. 15, available at: http://globalnational.in.ua/archive/15-2017/36.pdf (last accessed 15.09.2021).

3. Diachenko, Yu. A. (2017). Current status and features of the world exchange market performance [Suchasnyi stan ta osoblyvosti fun ktsionuvannia svitovoho birzhovoho rynku], Scientific Bulletin of the International Humanities University, No. 23, P. 51-54.

4. Kovalchuk, S. V., Drazhnitsya, S. A., Karpenko, V. L. (2018). World trends and tendencies of stock trading development at the present stage [Svitovi trendy ta tendentsii rozvytku birzhovoi torhivli na suchasnomu etapi], Entrepreneurship and trade, No. 23, P. 10-14.

5. Reznik, N. P. (2016). Features of functioning of the domestic exchange commodity market in modern conditions [Osoblyvosti funktsionuvannia vitchyznianoho birzhovoho tovarnoho rynku u suchasnykh umovakh], Collection of scientific works of the Interregional Academy of Personnel Management, No. 50, P. 115-118. 
6. Solodky, M. O. (2017). Problems and ways of developments of the commodity exchange market in Ukraine [Problemy ta napriamy rozvytku birzhovoho tovarnoho rynku v Ukraini], Electronic scientific professional publication "Effective Economics", No. 10, available at: http://www.economy.nayka.com.ua/?op=1\&z=5814 (last accessed 05.09.2021).

7. State Statistics Service of Ukraine. "Domestic trade. Number of exchanges" ["Statystychna informatsiia. Vnutrishnia torhivlia. Kilkist birzh"], available at: http://www.ukrstat.gov.ua/ (last accessed 10.09.2021).

8. Kukharets, V. V., Bului, O. H., Levkivska, L. M. (2021). Trends in the development of the stock market in the context of globalization of the world economy [Tendentsii rozvytku birzhovoho rynku v umovakh hlobalizatsii svitovoi ekonomiky], Electronic scientific professional publication "Effective Economics", No. 4, available at: http:// www.economy.nayka.com.ua/pdf/4_2021/92.pdf (last accessed 25.09.2021).

9. National Commission on Securities and Stock Market. "Market analysis" ["Analiz rynku"], available at: https://www.nssmc.gov.ua/news/insights/ (last accessed 10.09.2021).

10. SMIDA. "Issuers" ["Emitenty"], available at: https://smida.gov.ua/db/ (last accessed 12.09.2021).

\section{РЕФЕРАТИ РЕФЕРАТЫ ABSTRACTS}

\section{УДК 339.172; JEL Classification: Q 02 \\ Нестеренко В.Ю., Сідельнікова В.К. НАПРЯМИ АНАЛІЗУ БІРЖОВОЇ ДІЯЛЬНОСТІ В УКРАЇНІ}

Мета. формування переліку напрямів аналізу біржової діяльності в Україні та дослідження статистичних показників. Методика дослідження. В ході дослідження використовувалися методи аналізу і синтезу, метод логічного аналізу. Інформаційними ресурсами дослідження є електронні інформаційні ресурси і матеріали періодичних видань. Результати. В сучасних умовах України склалася ситуація, коли біржовий ринок виконує свої функції на дуже незадовільному рівні й не забезпечує реалізації головних аспектів біржової діяльності в ринкових умовах господарювання: не зважаючи на вражаючу чисельність бірж в Україні, в порівнянні з більшістю інших країн світу, систематично діють серед них не більше 30\%; періодичні стрімкі зростання кількості бірж в Україні $\epsilon$ результатом не підвищеного попиту на їх послуги 3 боку учасників торгів та результатом дії ринкових механізмів господарювання, а $€$ відображенням впливу введення в дію законодавчих актів та обмежень у зовнішній торгівлі окремими групами товарів, таких як обов'язкова біржова реєстрація експортних контрактів, тощо; не зважаючи на велику кількість товарних бірж, які спеціалізуються на торгівлі агропромисловими товарами, в Україні все ще відсутній постійно діючий ефективний біржовий аграрний ринок. Отже, необхідним є створення механізмів, які б забезпечили об'єктивну оцінку діяльності бірж з метою впровадження керуючих дій в напрямку їх розвитку в Україні. Першочерговим $\epsilon$ створення прозорої системи формування 
статистичних даних про діяльність товарних бірж в Україні, які реально відобразять тенденції розвитку цього ринку. Для відповідного статистичного дослідження необхідне розкриття наступних груп інформації та розрахунок показників: дослідження кількості, структури, розмірів бірж, аналіз темпів зростання кількості у прямому зв’язку з обсягами укладених угод; аналіз обсягів попиту та пропозиції на біржах з метою виявлення формально діючих бірж; аналіз біржового обороту; аналіз показників ділової активності на біржовому ринку; аналіз біржових цін; аналіз обсягів строкових контрактів та похідних фінансових інструментів, як механізмів реалізації процедури хеджування; аналіз показників ефективності діяльності біржових установ та загальних показників галузі; аналіз показників розвитку біржової інфраструктури. Наукова новизна. Уточнено перелік напрямів аналізу діяльності товарних бірж України та проаналізовано статистичні показники біржової діяльності. Практична значущість. Запропоновані висновки можуть бути використані у біржовому підприємництві та державному управлінні для формування ефективної системи аналізу біржової діяльності.

Ключові слова: біржова діяльність, аналіз, статистичні показники, товарні біржі, фондові біржі.

\section{УДК 339.172; JEL Classification: Q 02}

Нестеренко В.Ю., Сидельникова В. К. НАПРАВЛЕНИЯ АНАЛИЗА БИРЖЕВОЙ ДЕЯТЕЛЬНОСТИ В УКРАИНЕ

Цель. формирования перечня направлений анализа биржевой деятельности в Украине и исследование статистических показателей. Методика исследования. В ходе исследования использовались методы анализа и синтеза, метод логического анализа. Информационными ресурсами исследования являются электронные информационные ресурсы и материалы периодических изданий. Результаты. В современных условиях Украины сложилась ситуация, когда биржевой рынок выполняет свои функции на очень неудовлетворительном уровне и не обеспечивает реализации главных аспектов биржевой деятельности в рыночных условиях хозяйствования: несмотря на впечатляющее количество бирж в Украине, по сравнению с большинством других стран мира, систематически действуют среди них не более 30\%; периодический стремительный рост количества бирж в Украине является результатом не повышенного спроса на их услуги со стороны участников торгов и результатом действия рыночных механизмов хозяйствования, а является отражением влияния введения в действие законодательных актов и ограничений во внешней торговле отдельными группами товаров, таких как обязательная биржевая регистрация экспортных контрактов и т.д.; несмотря на большое количество товарных бирж, специализирующихся на торговле агропромышленными товарами, в Украине все еще отсутствует постоянно действующий эффективный биржевой аграрный рынок. Таким образом, необходимо создание механизмов, которые бы обеспечили объективную оценку деятельности бирж с целью внедрения управляющих действий в направлении их развития в Украине. Первоочередной является создание прозрачной системы 
формирования статистических данных о деятельности товарных бирж в Украине, которые реально отразят тенденции развития этого рынка. Для соответствующего статистического исследования необходимо раскрытие следующих групп информации и расчет показателей: исследование количества, структуры, размеров бирж, анализ темпов роста количества в прямой связи с объемами заключенных договоров; анализ объемов спроса и предложения на биржах с целью выявления формально действующих бирж; анализ биржевого оборота; анализ показателей деловой активности на биржевом рынке; анализ биржевых цен; анализ объемов срочных контрактов и производных финансовых инструментов, как механизмов реализации процедуры хеджирования анализ показателей эффективности деятельности биржевых учреждений и общих показателей отрасли; анализ показателей развития биржевой инфраструктуры. Научная новизна. Уточнен перечень направлений анализа деятельности товарных бирж Украины и проанализированы статистические показатели биржевой деятельности. Практическая значимость. Предложенные выводы могут быть использованы в биржевом предпринимательстве и государственном управлении для формирования эффективной системы анализа биржевой деятельности.

Ключевые слова: биржевая деятельность, анализ, статистические показатели, товарные биржи, фондовые биржи.

UDK 339.172; JEL Classification: Q 02

Nesterenko V. Yu., Sidelnikova V. K. DIRECTIONS OF ANALYSIS OF EXCHANGE ACTIVITIES IN UKRAINE

Purpose. Formation of the list of directions of the analysis of exchange activity in Ukraine and research of statistical indicators. Methodology of research. The study used methods of analysis and synthesis, the method of logical analysis. The information resources of the study are electronic information resources and materials of periodicals. Results. In the current conditions of Ukraine there is a situation when the stock market performs its functions at a very unsatisfactory level and does not ensure the implementation of the main aspects of exchange activities in market conditions: despite the impressive number of exchanges in Ukraine, compared to most other countries. not more than $30 \%$ of them; Periodic rapid growth in the number of exchanges in Ukraine is the result of increased demand for their services by bidders and the result of market mechanisms, but is a reflection of the impact of legislation and restrictions on foreign trade in certain groups of goods, such as mandatory exchange registration of export contracts, etc .; Despite the large number of commodity exchanges specializing in trade in agro-industrial goods, Ukraine still lacks a permanent efficient exchange agricultural market. Therefore, it is necessary to create mechanisms that would provide an objective assessment of the activities of exchanges in order to implement management actions in the direction of their development in Ukraine. The priority is to create a transparent system for generating statistical data on the activities of commodity exchanges in Ukraine, which will really reflect the development trends of this market. For the relevant statistical study it is necessary to disclose the following groups of information and calculate indicators: 
study of the number, structure, size of exchanges, analysis of growth rates in direct connection with the volume of transactions; analysis of supply and demand on exchanges in order to identify formally operating exchanges; exchange turnover analysis; analysis of indicators of business activity in the stock market; analysis of stock prices; analysis of the volume of futures contracts and derivative financial instruments as mechanisms for implementing the hedging procedure; analysis of performance indicators of exchange institutions and general indicators of the industry; analysis of indicators of exchange infrastructure development. Originality. The list of directions of the analysis of activity of commodity exchanges of Ukraine is specified and statistical indicators of exchange activity are analyzed. Practical value. The proposed conclusions can be used in exchange business and public administration to form an effective system of analysis of exchange activity.

Key words: exchange activity, analysis, statistical indicators, commodity exchanges, stock exchanges.

\section{Відомості про авторів / Сведения об авторах / About the Authors}

Нестеренко Валентина Юріївна - кандидат економічних наук, доцент, Харківський національний автомобільно-дорожній університет, доцент кафедри економіки i підприємництва, м. Харків, Україна; e-mail: valentinaonisiforova@gmail.com; ORCID: http://orcid.org/0000-0001-9899-8427. Моб. 099-499-14-28.

Нестеренко Валентина Юрьевна - кандидат экономических наук, доцент, Харьковский национальный автомобильно-дорожный университет, доцент кафедры экономики и предпринимательства, г. Харьков, Украина.

Nesterenko Valentyna - Candidate of Sciences (Economics), Associate Professor, Kharkov National Automobile and Highway University, Associate Professor at the Department of Economics and Entrepreneurship, Kharkiv, Ukraine.

Сідельнікова Владислава Костянтинівна - кандидат педагогічних наук, доцент, Харківський національний педагогічний університет імені Г.С. Сковороди, доцент кафедри економічної теорії, фінансів і обліку, м. Харків, Україна; e-mail: vladasid09@gmail.com; ORCID: http://orcid.org/0000-0002-38516067. Моб. 067-701-43-43

Сидельникова Вдадислава Константиновна - кандидат педагогических наук, доцент, Харьковский национальный педагогический университет имени Г.С. Сковороды, доцент кафедры экономической теории, финансов и учета, г. Харьков, Украина.

Sidelnikova Vladyslava - Candidate of Sciences (Pedagogical Sciences), Associate Professor, Kharkiv National Pedagogical University named after G.S. Skovoroda, Associate Professor at the Department of Economic Theory, Finance and Accounting, Kharkiv, Ukraine. 